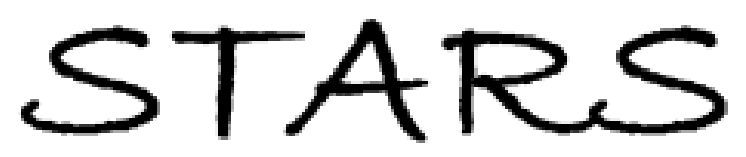

University of Central Florida

STARS

$1-1-2001$

\title{
Strategic interdependence in organizations: Deconglomeration and marketing strategy
}

P. Rajan Varadarjan

Satish Jayachandran

J. Chris White

University of Central Florida

Find similar works at: https://stars.library.ucf.edu/facultybib2000

University of Central Florida Libraries http://library.ucf.edu

This Article is brought to you for free and open access by the Faculty Bibliography at STARS. It has been accepted for inclusion in Faculty Bibliography 2000 s by an authorized administrator of STARS. For more information, please contact STARS@ucf.edu.

\section{Recommended Citation}

Varadarjan, P. Rajan; Jayachandran, Satish; and White, J. Chris, "Strategic interdependence in organizations: Deconglomeration and marketing strategy" (2001). Faculty Bibliography 2000s. 2987. https://stars.library.ucf.edu/facultybib2000/2987

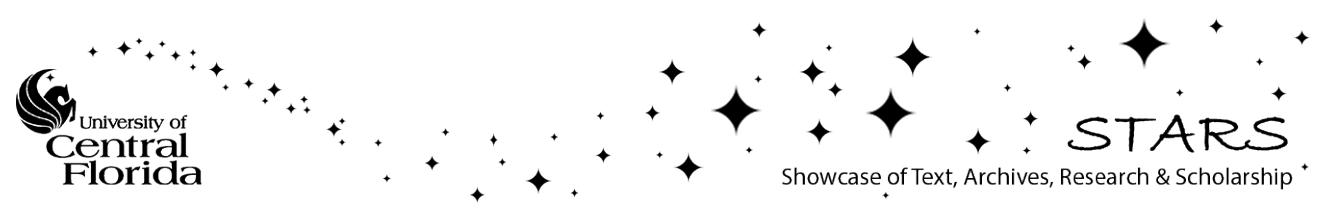




\section{P. Rajan Varadarajan, Satish Jayachandran, \& J. Chris White}

\section{Strategic Interdependence in Organizations: Deconglomeration and Marketing Strategy}

Although strategy exists at multiple levels in a firm (corporate, business, and functional), there is a dearth of research in marketing literature that focuses on the dependency among strategy at different levels. The authors address this issue by examining the relationship between deconglomeration and marketing strategy. Deconglomeration refers to the divestiture behavior of a conglomerate firm and the transformation of its business portfolio from one that is largely composed of several unrelated businesses to one composed of fewer and related businesses. Drawing on multiple theoretical perspectives, the authors propose a conceptual model delineating the environmental and organizational drivers of deconglomeration and its outcomes for marketing. The authors suggest that after deconglomeration, (1) a firm can be expected to be more competitor and customer oriented, (2) multimarket contact with competing firms and seller concentration will increase, (3) businesses retained by the firm will be more innovative and place greater emphasis on advertising compared with sales promotion, and (4) the firm's culture may become more externally oriented. Furthermore, the locus of decision making for marketing strategy may shift more toward senior management levels. In summary, changes in a firm's corporate strategy could lead to significant changes in the marketing strategy of its business units.

$\mathrm{n}$ a recent commentary advancing an agenda for increasing marketing knowledge use, Deshpandé (1999) stresses the need to break free from the shackles of functional silos in examining business problems and advocates research that is cross-disciplinary, cross-cultural, crossfunctional, and customer-centric in focus. In addition to the four Cs proposed by Deshpandé, a fifth $\mathrm{C}$ that merits consideration, particularly in the realm of strategy, is research characterized by a multilevel or cross-level focus. Strategy exists at multiple levels in an organization - corporate, business, and functional. Corporate strategy specifies the businesses in which a firm chooses to compete. Business strategy specifies how different businesses in the firm's portfolio will compete in the marketplace. Marketing strategy refers to the marketing activities and decisions related to generating and sustaining competitive advantage for the business (Day, Weitz, and Wensley 1990). Although strategy exists at multiple levels, the interdependencies among strategy at different levels remains relatively unexplored. Yet, as the PepsiCo example described next suggests, marketing strategies pursued by businesses often are influenced by changes in corporate strategy that manifest themselves as changes in the firm's portfolio of businesses.

P. Rajan Varadarajan is Calvin R. Guest Professor of Business, Department of Marketing, Texas A\&M University. Satish Jayachandran is Assistant Professor of Marketing, Darla Moore School of Business, University of South Carolina. J. Chris White is Assistant Professor of Marketing, University of Central Florida.
In 1996, PepsiCo divested its restaurant businesses (Pizza Hut, KFC, and Taco Bell) to focus on beverages and snack foods. Following the divestiture, PepsiCo undertook a major reorganization activity it branded as the "Power of One." The Power of One strategy encompasses efforts by Pepsico to promote beverages and salty snack products together. For example, retail stores are encouraged to display these products side by side. Furthermore, in negotiating for shelf space from supermarkets, PepsiCo promotes the combined profit potential of its range of products. Although the idea of promoting beverages and salty snacks together is not new, after PepsiCo divested the restaurant business, this strategy received the attention of top management and became the company's strategic focus (Hays 1999).

Changes in corporate strategy can derail long-pursued and often successful marketing strategies while affording opportunities for new ones. The potential impact of corporate strategy on marketing strategy makes it imperative that marketing researchers and managers understand the contours of the change and its effect on marketing. The intended contribution of this article is the focus it brings to research on the cross-level dependency of marketing strategy and the detailing of a research agenda on such issues. Specifically, we elucidate the influence of corporate strategy on marketing strategy by examining the drivers of deconglomeration and its outcomes for marketing. Deconglomeration refers to the divestiture behavior of a conglomerate firm and the transformation of its business portfolio from one composed of several largely unrelated businesses to one composed of relatively fewer and interrelated busi- 
nesses. ${ }^{1}$ It constitutes a corporate-level strategy decision to retain in the firm's portfolio only those businesses that, in the assessment of the top management of the firm, have the potential to leverage the firm's core competencies to emerge as major players in a global marketplace. Deconglomeration has been termed "a major evolutionary change for the American corporation" (Markides 1995, p. 8). In recent years, deconglomeration has been reshaping the landscape of corporate America by restructuring the business portfolios of conglomerate diversified firms from unrelated diversified to related diversified or focused (see Markides 1995). Case in point is the Sears Roebuck Company, which has retreated from a conglomerate strategy characterized in the business press as a one-stop shop for everything from socks to stocks. Subsequent to the divestiture of its Allstate insurance, Coldwell Banker real estate, Dean Witter brokerage, and Discover credit card businesses, Sears is currently focusing on its retailing business. ${ }^{2}$

In conglomerate growth through diversification, firms used the profits generated by their present businesses to

${ }^{1}$ Central to a firm's diversification strategy are decisions related to (1) the direction of diversification (e.g., related versus unrelated/conglomerate diversification), (2) the degree of diversification (e.g., high, moderate, and low levels of related or unrelated diversification) and (3) the mode of diversification (e.g., internal development, acquisition, merger, joint venture). As Markides (1995) notes, a strategy of related diversification in which the various businesses are structured around the firm's core competencies is expected to pay off through synergistic economies. In a strategy of unrelated or conglomerate diversification, although the various businesses may have no operational synergies, the firm is expected to benefit through financial economies.

${ }^{2}$ Although in some cases it is conceivable that a strategy of deconglomeration (guided by an objective assessment of the firm's core competencies) will lead to a firm returning to its roots, it is also possible to envision deconglomeration leading to a firm divesting businesses that composed its portfolio before conglomeration. Cases in point are Corning Incorporated and Dial Corporation. Founded in 1851, Corning was well known for more than a century for shaping glass into household consumer products such as Pyrex and Corning Ware brand kitchenware. As recently as 1995, it was a conglomerate whose portfolio was composed of five lines of business: consumer products (13\%), health care services $(39 \%)$, telecommunications (22\%), advanced materials (16\%), and information display (10\%). Following the divestiture of its health care division and consumer products division, the refocused and restructured Corning is still a maker of glass-based products, but of a very different kind. The company spins out glass in the form of more than 30 million kilometers of optical fiber annually, and the telecommunications division accounts for approximately $70 \%$ of the firm's annual revenues (Creswell 2000).

Over a period of time, the Greyhound Company, originally an intercity bus service firm, evolved into a conglomerate by diversifying into several businesses, including household cleanser products (e.g., detergents) and personal care toiletry products (e.g., bath soaps, deodorants), processed meat foods, and food catering service. The firm that emerged in the aftermath of deconglomeration is no longer in the intercity bus service business. It is a consumer products company currently operating under the name Dial Corporation. Dial's principal lines of business after deconglomeration are personal care products (Dial, Breck, and Tone brands), laundry products (Purex, Borateem, and Sta-Flo brands), specialty body care products (Sarah Michaels and Nature's Accents brands), air fresheners (Renuzit brand), and canned meats (Armour brand). finance entry into new, often unrelated businesses. Such diversification was justified by financial synergy considerations. The corporate headquarters, in this case, functioned as an internal capital market allocating funds on the basis of the relative market attractiveness of individual businesses and their relative competitive positions. However, in recent years, the role of the corporate headquarters seems to have changed from that of an arbiter of financial capital to one of a trustee of the firm's valuable resources, such as its brand, customer, and channel equity (i.e., market-based assets; see Srivastava, Sherwani, and Fahey 1998); human resources portfolio; and competencies portfolio. This change has been associated with the reorganization of businesses around a firm's core competencies and the divestiture of businesses that cannot leverage these competencies. A significant portion of the resources freed up by these divestitures tends to be redeployed toward enhancing the competitive position of the businesses retained through pursuit of market penetration (e.g., acquiring direct competitors, increasing market share), market development (e.g., entering new geographic markets), and product development (e.g., introducing new products in the markets presently served) strategies.

In essence, unlike the era of conglomeration that was guided by a corporate philosophy of growing by diversifying, the era of deconglomeration is being shaped by a corporate philosophy of growing by divesting. Although growing by divesting may sound like an oxymoron, it can be a viable road to enhancing the long-term performance of conglomerate firms through judicious business deletion and resource reallocation decisions. In summary, the guiding philosophy here is one of pursuing growth by focusing on the firm's core competencies instead of the previous philosophy of focusing on financial synergies. Consequently, we argue that the marketing behavior of the businesses constituting the firm's portfolio is likely to change. In an attempt to provide theoretical and practical insights into this issue to marketing academicians and managers, in the sections that follow we

-Propose a conceptual model delineating the antecedents and marketing-related outcomes of deconglomeration,

-Present research propositions that explicate the relationships delineated in the proposed model, and

-Propose an agenda for further research in this area.

\section{Drivers and Outcomes of Deconglomeration}

A conceptual model delineating the relationship between deconglomeration intensity and its drivers and outcomes is presented in Figure 1. Here, the focal construct, deconglomeration intensity, is modeled as a function of five sets of drivers: (1) macroenvironmental drivers, (2) corporate governance drivers, (3) behavior of referent firms, (4) market power, and (5) strategic variety. Deconglomeration intensity is conceptualized as the extent to which a conglomerate firm has divested businesses from its portfolio over a defined period - that is, the proportion of a firm's sales at time $t$ accounted for by businesses divested during the period $t$ to 


\section{Drivers}

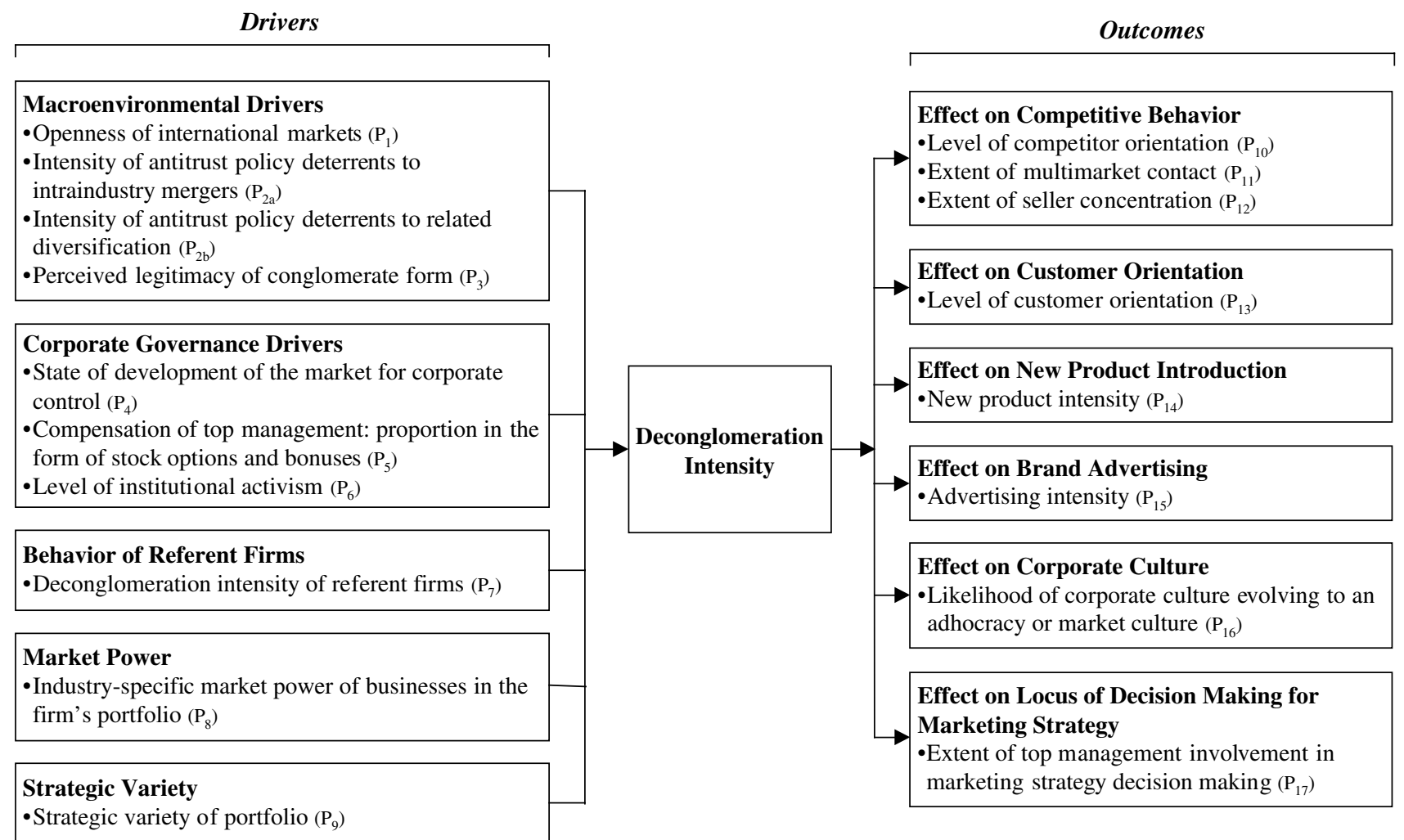

$\mathrm{t}+\mathrm{x} \cdot .^{3}$ As regards the outcomes of deconglomeration, our focus here is limited to those that are germane to marketing. Principal among these are (1) competitive behavior, (2) customer orientation, (3) new product introduction, (4) brand advertising, (5) corporate culture, and (6) locus of decision making for marketing strategy. We discuss the model in detail in the next two sections.

\section{Drivers of Deconglomeration}

\section{Macroenvironmental Drivers}

In recent years, several macroenvironmental factors, including increasing international market openness, changes in antitrust policies, and a decline in the perceived legitimacy of conglomerate structure, have influenced the divestiture behavior of conglomerate firms.

${ }^{3} \mathrm{We}$ wish to point out certain limitations in the conceptualization of deconglomeration intensity. Nuances such as harvesting and liquidation and partial divestment are not isolated by this conceptualization (see Hopkins 1991). Furthermore, it is conceivable that a conglomerate in dire financial straits might resort to divesting one or more of its core businesses rather than engaging in a deliberate strategy of deconglomeration and divestiture of noncore businesses. In such cases, the proposed conceptualization would capture divestment intensity (see Hoskisson, Johnson, and Moesel 1994) rather than deconglomeration intensity. Despite these limitations, to the extent that such behavior is rare, the proposed conceptualization is likely to provide a fairly robust measure of deconglomeration intensity.
International market openness. Before the 1990s, many international markets were characterized by high barriers to entry, often forcing firms to pursue growth by diversifying into new businesses within their home countries. Over the past decade, however, international markets have become considerably more open. In the more liberal international investment environment, firms now have a real choice between international market diversification (extending the geographic scope of their present businesses) and intranational business diversification (entering into new businesses in their presently served markets).

The theory of the multinational firm suggests that firms choose to become multinationals because, other conditions remaining the same, a firm that pursues international market diversification can be expected to outperform a firm that pursues intranational business diversification for the following reasons:

-Multinational corporations (MNCs), compared with firms pursuing intranational business diversification, have greater ability to exploit three sources of competitive advantage: differences in factor costs, scale economies, and scope. These sources of competitive advantage are open to all firms, but international market diversification provides MNCs with opportunities that are greater in degrees (Ghoshal 1987).

-The exposure of MNCs to highly diverse markets provides them with broader learning opportunities in comparison with purely domestic firms. This may enable MNCs to outperform their purely domestic rivals (Ghoshal 1987).

-Although extracting additional rents from the stock of skills and resources currently possessed by the firm is the impetus 
for entering new international markets, diversification into new businesses would entail either the acquisition or the internal development of new skills and resources. All else being equal, the latter approach is associated with greater outcome uncertainty.

Deconglomeration could therefore be a consequence of the opening up of many international markets - that is, an action by conglomerates to free up resources to pursue growth through more profitable international market diversification in core businesses in place of less profitable intranational business diversification.

$\mathrm{P}_{1}$ : The greater the openness of international markets, the greater is the deconglomeration intensity.

Antitrust policies. The antitrust policies of the 1960s and 1970s were dominated by a focus on preventing the emergence of concentrated market structures, presumably because of the strong influence of the structure-conductperformance (SCP) model in industrial organization economics. The SCP model (Bain 1956) views industry structure as the determinant of firm behavior and performance. A concentrated market structure, according to this model, facilitates oligopolistic coordination among firms, resulting in lower output, higher prices, and higher rates of return. To prevent the emergence of concentrated market structures, antitrust policy strongly discouraged intraindustry mergers and, to a degree, diversification into closely related businesses through mergers and acquisitions. Consequently, firms resorted to unrelated diversification in their quests for growth, which led to the emergence of conglomerates (Lichtenberg 1990).

Antitrust policy, however, changed radically in the 1980s. The Reagan administration's faith in the power of a free-market economy to promote higher economic performance led to less stringent enforcement of antitrust statutes and changes in antitrust policy (Schleifer and Vishny 1991). This reduced the institutional constraints placed on firms from growing in their present and/or related lines of businesses. These changes could have been influenced by the efficiency model of industrial organization economics (Demsetz 1973), which suggests that the relationship between concentration and profitability is due to efficiency differences between firms rather than the result of collusion and coordination as is postulated in the SCP model. Less stringent enforcement of and changes in antitrust statutes were conducive to intraindustry mergers, hostile takeovers, and leveraged buyouts. Consequently, there seems to have been a sharp increase in intraindustry mergers during the 1980s (see Schleifer and Vishny 1991). Therefore, it is conceivable that deconglomeration is a consequence of (1) the opportunities that became available to conglomerates to pursue growth in their core businesses through actions such as intraindustry acquisitions and diversification into related businesses and (2) the need to generate resources for such growth. Therefore,

$\mathrm{P}_{2}$ : The lower the intensity of antitrust policy deterrents to (a) intraindustry mergers and acquisitions and (b) diversification into related businesses, the greater is the deconglomeration intensity.
Legitimacy of the conglomerate organizational form. According to population (or organizational) ecology theory, firms exist primarily because of stakeholders' demands for reliability and accountability (Hannan and Freeman 1984). Reliability, to the shareholders of a firm, is the firm's ability to provide superior returns consistently, compared with the returns that shareholders can realize by pursuing alternative investment opportunities. Accountability refers to the ability of a firm to explain to its shareholders that resources have been used appropriately and that managerial actions taken are in the best interests of shareholders. Reliability and accountability provide an organizational form with legitimacy in the eyes of its stakeholders. Organizations must maintain reliability and accountability over long periods of time. This necessitates the development of routines and results in the institutionalization of processes. Institutionalization of processes can, however, lead to inertia, the inability to change as the environment demands. For new organizational forms to emerge, substantial stress needs to be created by a change in the resource space (or niche) that causes a particular organizational form to lose legitimacy on account of diminished reliability and accountability.

In recent years, conglomerate diversified firms have experienced a loss of legitimacy as a superior organizational form from the shareholders' point of view, because their reliability and accountability have become suspect. With few exceptions, conglomerate diversified firms have failed to provide reliable returns to shareholders compared with what shareholders could earn from investing in other organizational forms. Furthermore, the management of conglomerates may have failed to provide rational explanations for the advantage of the unrelated, diversified nature of its business portfolio. The gap between the desired and provided reliability and accountability could have prompted investors to move their capital to organizational forms perceived to be more reliable and accountable, such as related, diversified firms. Indeed, this is reflected in the phenomenon commonly referred to as "conglomerate discount" (i.e., the stock market imposes a discount on the share prices of conglomerate diversified firms; Heuskel 1996). The stress from this change in the niche may lead firms to adapt through deconglomeration. Therefore,

\footnotetext{
$\mathrm{P}_{3}$ : The lower the perceived legitimacy of the conglomerate diversified firm as an organizational form, the greater is the deconglomeration intensity.
}

\section{Corporate Governance Drivers}

The separation of ownership and management of firms, coupled with wide diffusion of ownership among a large number of shareholders, often diminishes the power of shareholders (principals) and provides managers (agents) considerable discretion over policy decisions. Agency theory explores these issues by analyzing situations that lead to such problems and drawing up contracts to mitigate them (for a review, see Bergen, Dutta, and Walker 1992; Jensen and Meckling 1976). Agency theory explains conglomeration as a consequence of differences in the risk preferences between managers and shareholders and an inability to control the consequent self-serving managerial behavior: 
-Managers may be inclined to reduce their employment risk by diversifying because higher levels of unrelated diversification are likely to reduce variance in cash flows and the risk of bankruptcy (Amihud and Lev 1981). However, excessive unrelated diversification may hurt the performance of the firm, because managers may not be able to control all the subsidiaries of the diversified firm appropriately and may not focus enough on innovation (Hoskisson and Hitt 1990). This creates a conflict of interest between managers and shareholders.

-Shareholders are constrained in their ability to control opportunistic behavior by managers because of the difficulty and/or expense of acquiring information. The board of directors, which usually has enough information on managerial behavior, is expected to control opportunistic behavior by managers (Fama and Jensen 1983). However, more often than not, management controls the selection of board members and the functioning of the board. Consequently, the power of the board to control opportunistic managerial behavior may be limited.

-It is possible to control managerial behavior through appropriate compensation schemes. Traditionally, however, the bulk of top management's compensation was tied to the size of the firm. Managerial self-interest, under the influence of such compensation plans, may have led to diversification through acquisition in order to increase the asset and revenue base of the company (see Fama and Jensen 1983).

During the 1980s, three mechanisms emerged to control or discipline managers who may be inclined to pursue corporate strategies that might be undesirable from the perspective of shareholders - the market for corporate control, managerial compensation linked to stock performance, and institutional activism in corporate governance. We discuss the impact of these three mechanisms on deconglomeration next.

The market for corporate control. The market for corporate control has emerged to discipline ineffective managers through takeover of firms (Fama and Jensen 1983). Conglomerates performing poorly are particularly strong candidates for external takeover. There are two ways in which the market for corporate control can lead to deconglomeration. First, after a takeover, the new owners often replace the managers. Therefore, high levels of unrelated diversification, originally sought by managers to reduce their employment risk, may increase employment risk in an active market for corporate control. Consequently, managers may pay heed to the threat of hostile takeovers and run the firm more efficiently (Walsh and Seward 1990). This may lead to a reduction in inefficient forms of diversification (from the shareholders' perspective) and consequently deconglomeration. Second, extremely high levels of debt are often used to finance takeovers. Such high levels of debt force new owners/managers to divest businesses selectively from the firm's portfolio to reduce the debt. The most logical candidates for divestiture are strategic business units (SBUs) with the least potential to leverage the firm's core competencies.

The extent to which the market for corporate control is likely to affect deconglomeration intensity will depend on how well developed the market for corporate control is in the country in which a firm is headquartered and its securities are primarily traded. Consider, for example, the differences in the stage of development of the market for corporate control alluded to in a Boston Consulting Group (Lewis and Peck 1991) study:
Financial markets and corporate ownership patterns have differed between the U.S./U.K. and German systems...: weaker companies are not as heavily discounted in the (German) stock market as in the U.S. As a result, Germany hasn't had a well-developed market for corporate control.... Takeovers, radical restructurings, and sales of lowperforming businesses-all familiar in the U.S. and the U.K.- - are rare in Germany and on most of the continent.

Therefore,

$\mathrm{P}_{4}$ : The more developed the market for corporate control, the greater is the deconglomeration intensity.

Managerial compensation. As noted previously, the bulk of top management's compensation traditionally has been tied to the size of the firm. This may have led to diversification through acquisitions intended to increase the asset and revenue base of the company (Fama and Jensen 1983). More recently, however, there has been a shift toward compensating top managers through stock options. When a large proportion of top managers' compensation is in the form of stock options, it ties their income closely to stock performance. This motivates managers to initiate actions conducive to increasing the market value of the firm. Therefore, the top management of a firm may divest businesses that adversely affect the firm's share price and, in turn, its own compensation (Hoskisson and Hitt 1994). Therefore,

$\mathrm{P}_{5}$ : The larger the proportion of top managers' total compensa-
tion that is in the form of stock options, the greater is the
deconglomeration intensity.

Institutional activism in corporate governance. During the past few decades, the structure of ownership of U.S. corporations has changed drastically. Institutional investors such as mutual funds and pension funds have emerged as major shareholders that own more than half the equity of public companies. Since the mid-1980s, institutional investors have become increasingly assertive in their quest to improve control mechanisms and curb managers' pursuit of self-serving strategies, such as high levels of unrelated diversification, that are likely to have an adverse impact on the market value of the firm (David 1996). This, in turn, may have led to deconglomeration. Therefore,

\section{$\mathrm{P}_{6}$ : The greater the level of institutional activism in the gover- nance of conglomerate firms, the greater is the deconglom- eration intensity.}

\section{Behavior of Referent Firms}

Institutional theory suggests that competitive behavior of firms is based on a collective cognitive framework that exists within firms (Porac and Rosa 1996). Firms compare their activities with those of their rivals and peers to enhance their understanding of strategies. When a firm takes an action, such as deconglomeration, other firms analyze the action and decide on its appropriateness. If the action were to be taken by firms that are leaders, it gets deeply embedded in the managerial cognitive construction of the competitive space and gains legitimacy. Legitimacy makes a strategic action less risky, from a political perspective, because it may be easier to justify the failure of actions that have a high 
degree of legitimacy. This furthers the tendency of other firms to copy the action (DiMaggio and Powell 1983).

To the extent that deconglomeration is perceived as conducive to superior firm performance or is undertaken by leading firms, other firms may copy this action (i.e., engage in mimetic action). Deconglomeration as a strategy has received a fair degree of acclaim from the popular press and investor support on Wall Street. This confers further legitimacy on deconglomeration as an effective strategy. Therefore, managers of conglomerate firms may, by mimetic action, engage in similar divestiture behavior. Thus, the enshrining of deconglomeration as a successful strategy in managerial cognitive constructions may be a reason for the divestiture behavior of conglomerate firms. Therefore,

$\mathrm{P}_{7}$ : The greater the deconglomeration intensity of referent firms, the greater is the deconglomeration intensity of the focal firm.

\section{Market Power}

Market power is the ability of a market participant or group of participants to influence price, quality, and the nature of the product in the marketplace (Shepherd 1970). In the past, generalized market power, determined by the overall size of the firm, was considered critical to overall firm performance. This belief could have acted as a driver of conglomeration, because firms may have accumulated businesses with the objective of increasing firm size. However, research evidence shows that, more than generalized market power, it is industry-specific market power that influences overall firm performance (Montgomery 1985). Furthermore, Montgomery finds that, on average, highly diversified firms do not have strong market positions in the product-markets in which they compete. ${ }^{4}$ Business divestitures by conglomerates can therefore be explained as a strategic behavior intended to free up resources in order to enhance the industry-specific market power of businesses in their portfolio. Therefore,

$\mathrm{P}_{8}$ : The lower the industry-specific market power of businesses in a conglomerate's portfolio, the greater is the deconglomeration intensity.

\section{Strategic Variety}

Strategic variety refers to differences in the strategic characteristics of the businesses in a firm's portfolio. It is a function of the unrelatedness of the businesses in the firm's portfolio and the diversity of the markets in which they operate. Excessive strategic variety of the businesses in a conglomerate's portfolio may motivate deconglomeration.

\footnotetext{
${ }^{4}$ Although empirical evidence suggests that, on average, highly diversified firms do not have strong market positions in the product-markets in which they compete, there are nevertheless exceptions. For example, over the years, General Electric has divested several businesses that had poor prospects for achieving the company's stated market share goal of being "number one or number two" in the respective industries and has redeployed the freed up assets in businesses that show greater promise of becoming dominant businesses within their respective industries.
}

The resource-based theory of the firm suggests that the sustainability of the competitive advantage of the various businesses in a firm's portfolio is a function of the core competencies of the firm (Barney 1991; Hunt and Morgan 1995; Prahalad and Hamel 1990). A firm's core competencies are based on the collective learning in the organization and built around resources that are valuable, rare, difficult to imitate, and not easily substitutable (Barney 1991). As noted by Prahalad and Hamel (1990, p. 81): "The real sources of advantage are to be found in management's ability to consolidate corporate wide technologies and production skills into competencies that empower individual businesses to adapt quickly to changing opportunities."

A firm's ability to consolidate and leverage competencies has implications for deconglomeration. Although a firm's core competencies can be leveraged for entry into related businesses, it may not be possible to leverage these resources for success in vastly unrelated businesses. Moreover, it may be difficult to generate and nurture firm-specific resources required for success in vastly different businesses. This follows from the likelihood that firm-specific resources are often socially complex (spread over many people or groups), causally ambiguous, and deeply embedded in organizational routines and processes (Barney 1991). The cognitive limitations of a firm's management may often act as a constraint on its attempts to learn, sustain, and leverage multiple firm-specific resources necessary for success in businesses with substantial strategic variety.

Coping with strategic variety becomes an even greater cognitive burden on management when the risks and complexities of multiple international markets are added. Addressing this burden, Prahalad and Bettis (1986, p. 494) state, "Divesting businesses to get more focus to the portfolio results from an implicit recognition that the demands on top management of strategic variety can be significant." Therefore, one of the reasons underlying deconglomeration may be the limitation of management's cognitive capability to handle the strategic variety and complexity that operating in many international markets with a diversified portfolio of unrelated businesses entails. Therefore,

$\mathrm{P}_{9}$ : The greater the strategic variety of a conglomerate firm's business portfolio, the greater is the deconglomeration intensity.

\section{Outcomes for Marketing}

Deconglomeration influences a firm's strategic imperatives, resource position, control systems, and market environment as follows:

1. Although the conglomerate firm relies on financial synergy-driven unrelated diversification as a basis for growth, after deconglomeration, in light of the fewer related businesses in its portfolio, the firm's growth depends on developing retained businesses through the pursuit of appropriate strategies.

2. Deconglomeration frees up resources-financial resources as well as top management's time-that previously were spent coordinating and controlling SBUs with very different knowledge bases. 
3. The strategic variety of the conglomerate firm often limits senior management's ability to control subsidiary operation through financial controls. After deconglomeration, the greater strategic focus of the firm enables senior management to employ strategic controls to guide managerial behavior.

4. Deconglomeration is likely to lead to more concentrated market structures in the markets in which the firm continues to operate. Furthermore, deconglomeration may also increase the relative market overlap of a firm with its rivals.

These changes can conceivably influence the firm's marketing strategy and processes. In the sections that follow, we examine in detail how one or more of these changes associated with deconglomeration influence aspects of firm behavior that are particularly relevant to marketing strategy researchers and marketing managers.

\section{Effect on Competitive Behavior}

In this section, we focus on the likely effect of deconglomeration on three organizational and market characteristics that have been extensively explored in marketing and strategy literature as factors that shape the competitive behavior of firms: competitor orientation, multimarket contact, and seller concentration.

Competitor orientation. Competitor orientation refers to the extent to which firms focus on learning about the actions of their rivals and reflects their propensity to respond to competitors (Narver and Slater 1990). The effectiveness of a firm's responses to the actions initiated by rivals critically influences its competitive advantage (Dickson 1992). Therefore, focusing on and responding to the actions initiated by competitors are critical for the long-term vitality of the firm.

The leaner business portfolio of a firm after deconglomeration is likely to provide top management with greater opportunities to focus on the market behavior of competitors. In effect, the greater availability of top management's time as a resource is likely to enhance the ability of the firm to focus on the market behavior of competing firms. Before deconglomeration, top management's attention would more likely have been focused on monitoring and coordinating the operations of different business units characterized by a high degree of strategic variety. Greater attention from top management to competitive activities can be expected to lead to greater competitor orientation for firms (Kohli and Jaworski 1990). Furthermore, the overall growth of a firm after deconglomeration is dependent on fewer businesses. Given the heightened importance of the growth of the retained businesses to the overall growth of the firm, the motivation of firms to monitor rivals is likely to be greater. Some of the resources made available by divestitures are likely to be deployed toward scanning the market and gleaning insights into competitors' behavior. This would help raise awareness of competitors' actions. In summary, after deconglomeration, the competitor orientation of the businesses retained by the firm is likely to increase because of (1) greater top management attention and (2) redeployment of resources toward market scanning.

$\mathrm{P}_{10}$ : The greater the deconglomeration intensity, the greater is the competitor orientation of the businesses retained by the firm.
Market overlap. Multimarket contact, a measure of market overlap, is defined as the number of markets in which the focal firm competes with its rivals as a percentage of its total number of markets. Research in the area of multimarket competition suggests that when the same firms compete against each other in many markets, the intensity of rivalry between them may decrease (Gimeno and Woo 1996; Jayachandran, Gimeno, and Varadarajan 1999). Meeting in multiple markets may increase firms' ability to deter one another from aggressive actions, because an action initiated by a firm in one market may provoke retaliatory actions by rivals in many markets. Therefore, a higher proportion of revenues would be at risk in the event of competitive retaliation under the multimarket context compared with the single-market context. The possibility that more revenue will be at risk may act as a constraining force and prevent firms from engaging rivals in intense competition (Edwards 1955).

The expectation that after deconglomeration the relative market overlap of a firm with competitors will increase is based on the premise that it is unlikely that any two firms in an industry would pursue similar patterns of product-market diversification over a period of time. In other words, it is unlikely that conglomerate firms would have business portfolios with many competing businesses. ${ }^{5}$ Therefore, the market overlap between conglomerate diversified firms, as a percentage of their total markets, may not be high. After deconglomeration, however, firms will see an increase in the percentage of market overlap with rivals. This overlap may increase further when firms redeploy resources freed up by divestitures into market expansion in the retained businesses in domestic and international markets.

$\mathrm{P}_{11}$ : The greater the deconglomeration intensity, the greater is
the multimarket contact of the firm with competing
firms.

Seller concentration. Seller concentration refers to the oligopolistic nature of a market and is an important predictor of competitive behavior. Increased seller concentration, according to the SCP perspective, is likely to provide firms with greater opportunities for tacit collusion, resulting in reduced emphasis on price competition and higher prices. Research evidence shows that businesses divested by conglomerates tend to be acquired by firms in closely related businesses or firms in the same industry. For example, studies show that

-In divestitures that followed acquisition, more than $70 \%$ of the assets acquired in hostile takeovers ended up being managed by firms in the same line of business as those assets.

\footnotetext{
${ }^{5}$ Consider, for example, the patterns of product-market diversification pursued during the 1960s, 1970s, and 1980s by Coca-Cola Inc. (Columbia Pictures entertainment, Maryland Club brand beverages, California Taylor brand wine beverages, Minute Maid brand fruit-based beverages, plastic cutlery business, pasta business, and desalination equipment business) and PepsiCo (Wilson Sporting Goods; North Atlantic Van Lines; Frito-Lay snack foods; and Pizza Hut, KFC, and Taco Bell chains of fast-food restaurants).
} 
-Within three years following leveraged buyouts, approximately $50 \%$ of the assets were sold to buyers in the same industry (see Schleifer and Vishny 1991).

Furthermore, as noted previously, after deconglomeration, a firm can be expected to redeploy some of the freed up resources toward acquisition of direct and/or peripheral competitors in the businesses in which the firm chooses to remain. Consequently, deconglomeration can be expected to lead to changes in the market structure of the industries from which a conglomerate exits, as well as the ones in which it chooses to remain. The net effect is that the industries from which a conglomerate exits and the ones in which it chooses to remain are likely to become more concentrated than before.

$\mathrm{P}_{12}$ : The greater the deconglomeration intensity, the greater is the seller concentration in the industries served by the businesses retained.

In summary, as a result of the influence of deconglomeration on competitor orientation, multimarket contact, and seller concentration, after deconglomeration, the competitive behavior of firms is likely to change. The specific nature of the change would depend on the relative influence of deconglomeration on each of these factors and is an empirical issue.

\section{Effect on Customer Orientation}

After deconglomeration, the relationship of a firm with customers will be centered on fewer businesses. Moreover, as a result of redeployment of resources freed up by divestitures to enhance the competitive position of the businesses that are retained, it can be expected that the retained businesses are likely to serve a much larger and more global customer base. The future growth of the firm after deconglomeration depends on the customer base of the retained businesses (rather than on customers inherited through acquisition of unrelated businesses in conglomerates). Consequently, firms are more likely to adopt a long-term orientation in their relationships with their customers after deconglomeration. This is likely to enhance the firm's commitment to satisfying customers' needs. Customer orientation involves keeping track of customers' needs and disseminating this information within the organization (Narver and Slater 1990). Greater customer orientation enables a firm to perceive customer dissatisfaction, should such a situation exist, and respond to the causes of customer dissatisfaction. Consequently, greater customer orientation can be expected to support the firm's efforts to retain customers as well as attract new customers in the markets served by its businesses. In effect, when the firm's relationship is centered on fewer businesses, the increased importance of both customer retention and attracting new customers for growth makes it imperative that firms become more customer oriented after deconglomeration.

Furthermore, it becomes possible for the firm to upgrade its customer support activities and become more customer oriented because of the resources made available by deconglomeration. The ability of the firm to scan markets, understand customers' needs better, and satisfy these needs can improve as a result of redeployment of resources to nurture businesses retained in the firm's portfolio. In summary, compared with its predecessor, the firm that emerges in the aftermath of deconglomeration is likely to (1) devote greater attention to acquiring information about customers' needs and responding to their needs and (2) deploy more resources toward these activities, making the businesses retained by the firm more customer oriented.

$\mathrm{P}_{13}$ : The greater the deconglomeration intensity, the greater is
the level of customer orientation of the businesses
retained by the firm.

\section{Effect on New Product Introduction}

New product development through innovations is critical to the long-term viability of firms. Some innovations may be informal as a result of digression from routine activities in firms and design improvements through "learning by doing," but to an increasing degree, innovation is the result of formal research and development (R\&D) (Scherer and Ross 1990). Informal innovative activities can be encouraged by building capabilities to learn by doing, and formal innovative activity through R\&D can be encouraged by instituting the right incentive systems to motivate managers to take risks. Deconglomeration can be expected to enable firms to improve their innovative ability by enhancing their capacity to learn by doing and by allowing them to use incentive systems more attuned to the promotion of risk taking by managers (Hoskisson and Hitt 1994). Furthermore, as explained next, firms are likely to pursue innovation with greater zeal after deconglomeration because of its heightened importance.

As Dosi (1988) notes, the heuristics of how to do things and how to improve them are often captured and embodied in organizational routines. Much of this knowledge, therefore, has the characteristic of tacitness. Through practice, repetition, and incremental improvements of such routines, firms develop the ability to explore opportunities in certain areas and create specific marketable products. By their very nature, such tacit skills are also likely to be of use only within a narrow domain of products or services in which they tend to be valuable. A conglomerate firm would need to nurture many different skills in its different businesses, whereas a related diversified firm may need to develop and sustain fewer skills that will be used in all its businesses. Therefore, it may become difficult for a conglomerate, compared with a related diversified firm that uses the same skills in many businesses, to continuously develop and enhance the many different tacit skills required for success in many different businesses because of the more limited use of such skills. This follows from the observation that tacit skills are refined and improved through repetition. In other words, the focus on core competencies associated with deconglomeration should enhance the ability of firms to sustain and develop tacit knowledge further. Therefore, deconglomeration and organizing a firm around its core competencies may improve its ability to undertake informal innovative activity.

Innovative activities through $R \& D$ in firms often involve substantial degrees of risk because the technical and commercial outcomes of research activities cannot be determined accurately ex ante. Most R\&D projects are of a longterm nature and thereby are inimical to short-term profitability. In a conglomerate firm, strategic control (i.e., the 
control of different businesses in the portfolio by evaluation of the strategies employed by them to compete) is difficult. The sheer strategic variety of the businesses in the corporate portfolio and the large spans of control will limit the ability of top management to exercise strategic control. This, in turn, may lead to a "by the numbers" orientation in which financial data are exclusively emphasized for control purposes (Hoskisson and Hitt 1988) and top management uses financial rather than strategic criteria to evaluate the performance of SBU managers. Typically, financial criteria such as return on assets and return on sales are short-term focused, whereas strategic criteria, designed to evaluate the quality of strategies, can be long-term oriented. Exclusive reliance on short-term-oriented financial criteria by conglomerates could lead to a reduction in formal R\&D activity in firms. The use of strategic controls in conjunction with financial controls to influence managerial behavior, a greater possibility after deconglomeration, may alleviate this problem (Hoskisson and Hitt 1994). Furthermore, some of the resources freed up by deconglomeration could be used for expansion of R\&D programs.

Reduction in a firm's debt after deconglomeration can also be expected to cause an upswing in R\&D investment in firms (Hitt, Hoskisson, and Ireland 1990; Hoskisson and Hitt 1994). Conglomerate firms often use debt as a mode of financing diversification. A firm's debt holders are typically risk averse and may not encourage long-term-oriented R\&D activity. Therefore, deconglomeration is likely to enhance the innovative capability of firms. In summary, both informal and formal innovation is likely to experience an upswing in the aftermath of deconglomeration. Consequently, new product intensity (i.e., the percentage of revenues derived from new products) may increase in the businesses retained by the firm after deconglomeration.

$\mathrm{P}_{14}$ : The greater the deconglomeration intensity, the greater is the new product intensity in the businesses retained by the firm.

\section{Effect on Brand Advertising}

The greater ability of the firm to use strategic controls after deconglomeration can also be expected to influence the relative emphasis of its businesses on brand advertising and sales promotion in the marketplace. Brand equity, a marketbased asset of immense value to the firm, is a function of customers' awareness and favorable attitudes toward a brand. A firm that develops brands of superior equity can leverage the equity to improve its cash flows and thereby generate shareholder value. Apart from superior product attributes, brand equity may be created by the use of extensive advertising promoting a brand's image (Srivastava, Sherwani, and Fahey 1998). Developing brand equity through image advertising is essentially a long-term activity necessitating considerable advertising expenditures.

Since the 1970 s and continuing into the late 1980s, advertising expenditure as a percentage of total marketing communications expenditures has shrunk considerably, whereas expenditure on sales promotion has seen a corresponding increase. Although many reasons can be given for the relative decline in the use of advertising and the increas- ing use of sales promotion, one critical reason has been the short-term orientation of firms and the corresponding pressure on managers to produce immediate sales results (Blattberg and Neslin 1989). Sales promotion essentially involves the use of incentives (1) to induce the trade and consumers to buy a brand and (2) to motivate and encourage the sales force to sell it. The incentive, which could take different forms, changes the value proposition of the brand temporarily. Sales promotion programs typically are used to boost the sales of the brand temporarily by employing a stronger short-term push strategy. However, this tactic may have serious long-term drawbacks. First, the increase in promotion expenditures often comes at the expense of advertising to build the brand's equity. Second, by frequently employing promotions, manufacturers condition customers to become deal prone-to buy only when the brand is on promotion. In other words, frequent promotions change the value proposition of the brand in the consumers' perception in the direction of the temporary value proposition created by the promotion. Therefore, frequent promotions could dilute the equity of the brand (Shimp 1999).

As noted, frequent promotions are often a result of shortterm-oriented policies. Such policies, as observed previously, are more likely in conglomerate firms because of the greater tendency in such firms to use financial controls exclusively. After deconglomeration, a firm is more likely to use strategic controls in conjunction with financial controls. Furthermore, in the more focused firms that emerge from deconglomeration, the role of top management is more likely to be that of custodian of the firm's resources such as brand equity than that of an arbiter of financial capital. These changes are likely to encourage long-term efforts at building the equity of the brand through advertising and other activities. Thus, deconglomeration is likely to result in an increase in advertising expenditure and a corresponding decrease in sales promotion activities.

$\mathrm{P}_{15}$ : The greater the deconglomeration intensity, the greater is the advertising intensity (ratio of advertising expenditures to total promotion expenditures) of the businesses retained by the firm.

\section{Effect on Corporate Culture}

Corporate culture has been defined as a set of values shared by the members of an organization (Deshpandé and Webster 1989). Primarily, corporate culture guides managers into acceptable behaviors implicitly and thus reduces the need for formal monitoring (Deshpandé, Farley, and Webster 1993). Organizations benefit from developing a strong culture that is consistent with achieving their desired objectives. Two dimensions characterize corporate or organizational culture. The first dimension ranges from organic to mechanistic processes. Organic processes refer to a firm's focus on flexibility, spontaneity, and individuality, whereas mechanistic processes refer to an organization's focus on control, stability, and order. The second dimension represents at its two extremes the extent to which a firm focuses on internal maintenance and external positioning. Internal maintenance refers to the emphasis on the extent to which activities are smoothed and integrated within the organization to enhance 
efficiency. External positioning is the emphasis of the organization on competition and achieving differentiation in the marketplace (Deshpandé, Farley, and Webster 1993).

In reference to these dimensions, Deshpandé, Farley, and Webster (1993) distinguish between four modal cultures-market, clan, hierarchical, and adhocracy. A market culture emphasizes competitive advantage and market superiority. Loyalty, tradition, and internal maintenance are viewed as critical in the clan culture. The hierarchical culture emphasizes predictability and smooth operations. Innovativeness, entrepreneurship, and risk taking are viewed as critical for success in adhocracy cultures. It should be noted, however, that though these cultures are not necessarily mutually exclusive, over time one type of culture might emerge dominant in a firm.

A conglomerate firm must integrate and run many unrelated businesses, none of which is likely to receive a high degree of attention from top management. These organizations may emphasize internal maintenance and predictability because of the need to run unrelated businesses smoothly. It is more likely that under such conditions firms may emphasize loyalty and tradition or have norms that encourage a high degree of predictability. This follows from the possibility that managerial information processing abilities are likely to be restricted in a conglomerate firm. This, in turn, would necessitate an emphasis on cultures that encourage loyalty and predictability, in which lower-level managers can be expected to behave in ways considered desirable by senior management without a high degree of monitoring. In other words, a conglomerate is more likely to focus on efficiency and encourage clan or hierarchical cultures.

In contrast, the relatively more focused firms that emerge in the aftermath of deconglomeration are likely to encourage cultures that emphasize concentrating on competition and building competitive advantage. Furthermore, they may also focus on risk-taking cultures that emphasize innovation. This follows from the need of focused firms to grow through competitive activities that snare market share from competitors or through innovative activities that help market development. These firms are less likely to emphasize cultures that attempt to make the organization predictable and efficient in place of ones that emphasize aggressive market actions and innovations. In summary, after deconglomeration, firms are more likely to develop a corporate culture of the market or adhocracy types than the clan or hierarchical types.

$\mathrm{P}_{16}$ : The greater the deconglomeration intensity, the greater is the likelihood of the firm developing an adhocracy or market culture as opposed to a clan or hierarchical culture.

\section{Effect on Locus of Decision Making for Marketing Strategy}

Issues related to marketing's influence within the firm, relative to other functional areas, have received considerable attention in marketing literature (Homburg, Workman, and Krohmer 1999; Walker and Ruekert 1987). A related issue is top management's influence in marketing strategy decisions and marketing's influence in corporate strategy decisions. As noted previously, strategy can be broadly construed as existing at the corporate, business, and functional levels in a firm. Correspondingly, strategic decision-making authority also tends to be distributed among these different levels in the firm. In other words, it is possible to distinguish between the locus of strategy (marketing, business, and corporate strategy) and the locus of decision making (marketing, business, and corporate management levels) (Varadarajan and Clark 1994). Deconglomeration can be expected to result in an upward shift in the locus of decision making for some of the marketing strategy decisions from the marketing function to the business and/or corporate levels.

Research shows that the more diversified the firm, the more time is spent on corporate-level planning rather than business-level planning (Leontiades and Tezel 1981). After deconglomeration, when the firm's portfolio is composed of fewer businesses, the demands placed on top management's time toward addressing portfolio management issues such as business addition and deletion and resource allocation are likely to diminish. Deconglomeration can therefore be expected to lead to cuts in staff and reductions in bureaucracy, which in turn places corporate executives in closer contact with business units (Hoskisson and Hitt 1994; Hoskisson and Turk 1990). Furthermore, the future growth of the firm becomes more dependent on the growth of businesses retained through marketing-oriented activities such as building brand equity and improving customer satisfaction. This heightens the likelihood of top management becoming more involved in marketing and business strategy decisions as well as boundary-spanning activities (e.g., greater and more frequent interface with customers, channel members, and the marketplace at large). Therefore,

\footnotetext{
$\mathrm{P}_{17}$ : The greater the deconglomeration intensity, the greater is the extent of top management's involvement in marketing strategy decision making.
}

\section{Future Research Directions}

This article has the potential to spur research pertaining to the proposed conceptual model as well as in other related areas. We first discuss issues related to the empirical testing of the conceptual model and elaborate on construct operationalization. After this, we discuss other potential issues for research in related areas.

\section{Issues in Model Testing}

The proposed model lends itself to testing in its entirety as well as in a modular manner (i.e., sections of the model delineating the linkages of [1] drivers to deconglomeration intensity and [2] deconglomeration intensity to outcomes). A brief explication of the rationale underlying the latter approach is perhaps required. Over a period spanning almost two decades, conglomerate firms have, to varying degrees, restructured their business portfolios through divestitures. Looking backward, it is important to gain insights into the extent to which the antecedent factors delineated in the model explain the portfolio-restructuring behavior of conglomerates. In this regard, an empirical study testing the relationships between deconglomeration intensity and its antecedents could provide valuable insights. Alternatively, because many firms (particu- 
larly in the United States) have already undergone deconglomeration, looking forward, it is critical to focus on the relationship between deconglomeration intensity and its hypothesized outcomes. In other words, depending on the perspective, the model could be tested in full or in two modules.

Alternative conceptualizations of the focal construct. In the proposed model, the focal construct is conceptualized as deconglomeration intensity. The model, however, is amenable to alternative conceptualizations of this construct. For example, the focal construct may be conceptualized as a nominal variable (the predeconglomeration and postdeconglomeration firm), where deconglomeration is perceived as a discrete event. In this case, testing the model would involve examinations of (1) how the antecedent conditions lead to a change in the status of the firm and (2) how this change in status influences the subsequent marketing behavior of the businesses in the firm's portfolio.

Alternative empirical settings. The model can be tested in an array of empirical settings, such as (1) a multicountry, longitudinal study; (2) a single-country, longitudinal study; (3) a multicountry, cross-sectional study; and (4) a singlecountry, cross-sectional study of a sample of firms. Testing the model longitudinally would entail examining the relationship between deconglomeration intensity and the extent of change in the antecedent variables (e.g., the degree and direction of change in the intensity of antitrust policy deterrents to intraindustry mergers) over a defined multiyear time frame. This can be studied in a single-country or multicountry setting. A cross-sectional study in a single-country setting, though feasible, would be somewhat limiting, because for some of the antecedent constructs, variance can be expected only in a multicountry setting.

Furthermore, only a longitudinal research design would allow for the inclusion and assessment of the relative effect of the construct "openness of international markets." Intrinsically, this is a global-level construct that varies over time. The world at large is more open to international trade and foreign direct investments now than before and is likely to be even more open in the future. In other words, a crosssectional design would involve testing a reduced model of the antecedents to deconglomeration. However, the full model can be tested for the consequences section. Both the full model and the submodels, however, are amenable to testing as specified in a cross-sectional setting by means of perceptual measures in place of objective measures (e.g., management's perceptions of the openness of international markets, intensity of antitrust policy deterrents to intraindustry mergers, as predictors of deconglomeration intensity). In summary, we wish to emphasize that the proposed model can be tested with a variety of approaches.

Data sources and construct operationalization. Testing of the full model or the submodels can be accomplished through secondary data (e.g., objective archival measures of the openness of international markets), primary data (e.g., managers' perceptions of advertising intensity before and after deconglomeration), or some combination of both. In Table 1, we summarize some potential measures of the constructs that can be developed mostly from archival data sources. The proposed approaches to construct operationalization in Table 1 are intended to be suggestive and are therefore in need of further refinement. A detailed discussion of measurementrelated issues is beyond the scope of this article.

\section{Other Related Research Issues}

The case of premium conglomerates. Although deconglomeration has indeed been a major force in reshaping the contemporary corporate landscape and has been motivated by a variety of drivers delineated in Figure 1, a small minority of firms continues to operate successfully as conglomerate, diversified firms. A Boston Consulting Group study (Heuskel 1996) reports that the distinguishing characteristics of "premium conglomerates" are their executives' skills in managing complexity. According to the study, premium conglomerates excel in three managerial tasks:

-Making acquisitions only when the competitive logic is compelling and not hesitating to divest businesses that are competitively at a disadvantage or are a poor fit,

-Managing portfolios of businesses as well as people and ideas (e.g., initiatives to replicate best practices across the company), and

-Mobilizing and deploying capabilities to breach competitive barriers and enter new businesses (i.e., making complexity their ally).

A closer examination of these three areas of excellence for premium conglomerates reveals their ability to overcome the weaknesses that beset the typical conglomerate. The existence of such firms neither negates the occurrence of deconglomeration nor invalidates the more general drivers and implications of deconglomeration. Rather, these exceptions provide an opportunity for further research. A detailed discussion of endogenous (e.g., leadership style, organizational structure, systems) and exogenous (e.g., structural characteristics of the industries) factors underlying the superior performance of premium conglomerates is beyond the scope of this article. However, we recognize its importance in the broader context of enhancing the understanding of the linkages among environment, strategy, competitive advantage, and firm performance.

Research on product elimination. The literature in marketing devoted to the study of product deletion decisions (Boulding, Morgan, and Staelin 1997; Montgomery and Urban 1969) has a long history. Many of the theories we used in this article to explain business deletion decisions can be leveraged to enhance the understanding of deletion decisions at the product and brand levels. In other words, although we focus on explaining business deletion decisions of firms, the theories explicated in this article could aid marketing managers and marketing researchers in understanding better the forces that shape a business's portfolio of products and brands.

Resource redeployment and brand rationalization. As noted previously, deconglomeration is associated with redeployment of resources from businesses divested to businesses retained by the firm. The pattern and mode of such redeployment is an important issue for further research. Although we indicate the broad redirections of such redeployment, an investigation of the specific directions of this redeployment could help illuminate the process behind the change in firm 
TABLE 1

Drivers and Outcomes of Deconglomeration: Construct Operationalization Issues ${ }^{a}$

\begin{tabular}{|c|c|}
\hline Construct & Operationalization \\
\hline $\mathrm{P}_{1}$ : International market openness & Foreign direct investment over a specific period \\
\hline $\begin{aligned} \mathrm{P}_{2 \mathrm{a}} \text { : Intensity of antitrust policy } \\
\text { deterrents to intraindustry } \\
\text { mergers and acquisitions }\end{aligned}$ & Number of horizontal mergers and acquisitions over a specific period \\
\hline $\begin{array}{l}\mathrm{P}_{2 \mathrm{~b}} \text { : Intensity of antitrust policy } \\
\text { deterrents to diversification into } \\
\text { related businesses }\end{array}$ & $\begin{array}{l}\text { Number of mergers and acquisitions among related businesses over a specific } \\
\text { period }\end{array}$ \\
\hline$P_{3}:$ Legitimacy of organizational form & Share price penalty for conglomerate diversification \\
\hline $\begin{array}{l}\mathrm{P}_{4}: \text { State of development of the } \\
\text { market for corporate control }\end{array}$ & Number of takeovers during a specific period \\
\hline $\begin{array}{l}\mathrm{P}_{5}: \text { Composition of top management } \\
\text { compensation }\end{array}$ & $\begin{array}{l}\text { Ratio of the value of long-term options (stock option grants, share grants, and } \\
\text { performance incentives) to total compensation }\end{array}$ \\
\hline$P_{6}:$ Level of institutional activism & $\begin{array}{l}\text { A count measure of the number of instances of announced activism over a certain } \\
\text { period (David 1996) }\end{array}$ \\
\hline $\mathrm{P}_{7}:$ Behavior of referent firms & Number of conglomerate firms engaging in deconglomeration over a specific period \\
\hline $\mathrm{P}_{8}:$ Industry-specific market power & Market share of Business $X$ in the firm's portfolio \\
\hline$P_{9}:$ Strategic variety & $\begin{array}{l}\text { A measure combining the relatedness of businesses in a firm's portfolio and the } \\
\text { number of markets in which it operates }\end{array}$ \\
\hline $\mathrm{P}_{10}:$ Competitor orientation & $\begin{array}{l}\text { Extent to which firms focus on learning about the actions of their rivals (Narver and } \\
\text { Slater 1990) }\end{array}$ \\
\hline$P_{11}:$ Multimarket contact & $\begin{array}{l}\text { Count number of market contacts as a percentage of total number of markets } \\
\text { (Gimeno and Woo 1996) }\end{array}$ \\
\hline $\mathrm{P}_{12}:$ Seller concentration & Combined market share of the four largest businesses in the industry \\
\hline $\mathrm{P}_{13}:$ Customer orientation & $\begin{array}{l}\text { Expenditure on customer support and customer information generation as a } \\
\text { percentage of sales }\end{array}$ \\
\hline$P_{14}:$ New product intensity & Number of new products/total sales (Hitt, Hoskisson, and Ireland 1990) \\
\hline$P_{15}:$ Advertising intensity & Advertising expenditure/total promotion expenditure \\
\hline$P_{16}:$ Organizational culture & $\begin{array}{l}\text { Measure of adhocracy, clan, hierarchy, or market culture (Deshpandé, Farley, and } \\
\text { Webster 1993) }\end{array}$ \\
\hline$P_{17}:$ Locus of decision making & $\begin{array}{l}\text { Percentage of time allocated to marketing strategy decision making by top } \\
\text { management }\end{array}$ \\
\hline
\end{tabular}

aAs is detailed in the text of the article, several of the constructs listed in the table are amenable to operationalization as perceptual measures; for example, on a five-point scale, managers' perceptions of the intensity of antitrust policy deterrents to intraindustry mergers and acquisitions can be measured "much greater than before," "greater than before," "about the same," "lower than before," and "much lower than before."

behavior after deconglomeration. The importance of such issues is highlighted in a recent study by Capron and Hulland (1999) that examines the extent to which firms redeploy three key marketing resources (brand names, sales forces, and general marketing expertise) after horizontal acquisitions.

Resource redeployment is reflected in the brand rationalization activities that firms often undertake after deconglomeration and the subsequent acquisitions of competitors of the businesses retained in order to pursue focused growth. In these cases, the firm will likely inherit several brand names in the product categories in which it already competes. Brand rationalization-related issues could be expected to assume center stage in those firms, which through one or more intraindustry acquisitions inherit the rights to more brand names than they view as optimal.
Brand-related issues that such firms may be required to address include (1) deciding which brand names to retain and phase out, (2) pursuing opportunities for brand consolidation through brand fusion/dual branding (e.g., melding of currently owned brand names and inherited brand names), and (3) organizing retained brand names into categories such as corporate-, business-, and product-level brand names or global brands, multicountry regional brands, country-specific national brands, and country-specific regional brands.

Research on other cross-level issues. The primary focus of this article was a cross-level strategic issue: the implications for marketing of a corporate-level strategic decision. At a more fundamental level, it is conceivable that corporate strategy, in turn, is influenced by functional-level 
and business-level strategies. The manner in which key businesses in a firm's portfolio choose to compete could influence the portfolio composition if the strategic imperatives of different businesses are conflicting. Furthermore, functional-level strategies (R\&D strategy, financial strategy, marketing strategy, and operations strategy) could constrain a firm's portfolio of businesses if the strategies employed by the functional areas of different businesses are conflicting.

Yet another cross-level issue that merits the consideration of marketing strategy researchers is the role that top management's characteristics play in the market-level behavior of firms. Strategy researchers have taken the upper-echelons approach to study how idiosyncratic processes and biases in top management's behavior influence the strategies adopted by firms. This approach is guided by the view that an organization reflects its top executives' perspectives. Therefore, the characteristics and functioning of top management could be a crucial determinant of organizational behavior (Hambrick and Mason 1984). Hambrick, Cho, and Chen (1996) suggest that there is a need to examine how top management team characteristics influence microcompetitive behavior, supporting the need for cross-level research. This is an area in which marketing academicians can play a significant role.

\section{Conclusion}

In this article, we examine the dependency of marketing strategy on corporate strategy by developing a model that delineates the drivers and outcomes of deconglomeration. As detailed in the article, the corporate strategy shift that gave rise to deconglomeration is likely to have significant implications for marketing. Specifically, the portfolio of businesses managed by a firm could play a fundamental role in determining the market-level strategies of the businesses. The strategic role of marketing in organizations is also likely to be reshaped in the more focused firms that emerge after deconglomeration.

This article contributes to research in marketing strategy by highlighting cross-level strategic interdependencies. We elaborate on the changes in marketing strategy and processes in the focused firm that emerges after deconglomeration. In the process, we focus the attention of marketing scholars and managers on a critical phenomenon that has reshaped the world of business. The theoretical insights that we provide in this regard can also be leveraged into enhancing the understanding of product deletion decisions of firms. We provide guidelines for empirical research by developing research propositions and discussing measurement issues of critical constructs. More generally, we hope to spur additional research in the area of strategic interdependencies in organizations.

\section{REFERENCES}

Amihud, Yakov and Baruch Lev (1981), "Risk Reduction as a Managerial Motive for Conglomerate Mergers," RAND Journal of Economics, 12 (Autumn), 605-17.

Bain, Joseph (1956), Barriers to Competition. Cambridge, MA: Harvard University Press.

Barney, Jay B. (1991), "Firm Resources and Sustained Competitive Advantage," Journal of Management, 17 (March), 99-120.

Bergen, Mark, Shantanu Dutta, and Orville C. Walker Jr. (1992), "Agency Relationships in Marketing: A Review of the Implications and Applications of Agency and Related Theories," Journal of Marketing, 56 (July), 1-24.

Blattberg, Robert C. and Scott A. Neslin (1989), "Sales Promotion: The Long and the Short of It," Marketing Letters, 1 (1), 81-97.

Boulding, William, Ruskin Morgan, and Richard Staelin (1997), "Pulling the Plug to Stop the New Product Drain," Journal of Marketing Research, 34 (February), 164-76.

Capron, Laurence and John Hulland (1999), "Redeployment of Brands, Sales Forces, and General Marketing Management Expertise Following Horizontal Acquisitions: A ResourceBased View," Journal of Marketing, 63 (April), 41-54.

Creswell, Julie (2000), "The New Old Thing," Fortune, 141 (March 20), 124-26.

David, Parthiban (1996), "Corporate Governance, Strategy, and Performance: Antecedents and Consequences of Activism by Institutional Investors," unpublished doctoral dissertation, Texas A\&M University.

Day, George S., Barton Weitz, and Robin Wensley (1990), The Interface of Marketing and Strategy. Greenwich, CT: JAI Press.

Demsetz, Harold (1973), "Industry Structure, Market Rivalry, and Public Policy," Journal of Law and Economics, 16 (April), 1-9. Deshpandé, Rohit (1999), "Introduction: 'Foreseeing Marketing,'” Journal of Marketing, 63 (Special Issue), 164-67.

_ John U. Farley, and Frederick E. Webster Jr. (1993), “Corporate Culture, Customer Orientation, and Innovativeness in Japanese Firms: A Quadrad Analysis," Journal of Marketing, 57 (January), 23-37. and Frederick E. Webster Jr. (1989), "Organizational Culture and Marketing: Defining the Research Agenda," Journal of Marketing, 53 (January), 3-15.

Dickson, Peter R. (1992), "Toward a General Theory of Competitive Rationality," Journal of Marketing, 56 (January), 69-83.

DiMaggio, Paul J. and Walter W. Powell (1983), "The Iron Cage Revisited: Institutional Isomorphism and Collective Rationality in Organizational Fields," American Sociological Review, 48 (April), 147-60.

Dosi, Giovanni (1988), "Sources, Procedures, and Microeconomic Effects of Innovation," Journal of Economic Literature, 26 (September), 1120-71.

Edwards, Corbin D. (1955), "Conglomerate Bigness as a Source of Power," in Business Concentration and Policy. Princeton, NJ: Princeton University Press, 331-52.

Fama, E.F. and M.C. Jensen (1983), "Separation of Ownership and Control," Journal of Law and Economics, 26 (June), 301-25.

Ghoshal, Sumantra (1987), "Global Strategy: An Organizing Framework," Strategic Management Journal, 8 (September/ October), 425-40.

Gimeno, Javier and Carolyn Y. Woo (1996), "Hypercompetition in a Multimarket Environment: The Role of Strategic Similarity and Multimarket Contact on Competitive De-escalation," Organization Science, 7 (May/June), 322-41.

Hambrick, Donald C., Theresa Seung Cho, and Ming-Jer Chen (1996), "The Influence of Top Management Team Heterogeneity on Firms' Competitive Moves," Administrative Science Quarterly, 41 (December), 659-84.

and Phyllis A. Mason (1984), "Upper Echelon: The Organization as a Reflection of Its Top Managers," Academy of Management Review, 9 (April), 193-206.

Hannan, Michael T. and John Freeman (1984), "Structural Inertia and Organizational Change," American Sociological Review, 49 (April), 149-64.

Hays, Constance L. (1999), “An Aisle Unto Itself? Pepsi’s Vision: All of Its Eggs in One Shopping Basket," New York Times, (July 31), C1. 
Heuskel, Dieter (1996), Premium Conglomerates. Boston: The Boston Consulting Group.

Hitt, Michael A., Robert E. Hoskisson, and R. Duane Ireland (1990), "Mergers, Acquisitions and Managerial Commitment to Innovation in M-Form Firms," Strategic Management Journal, 11 (Summer), 29-47.

Homburg Christian, John P. Workman Jr., and Harley Krohmer (1999), "Marketing's Influence Within the Firm," Journal of Marketing, 63 (April), 1-17.

Hopkins, Donald H. (1991), "Acquisition and Divestiture as a Response to Competitive Position and Market Structure," Journal of Management Studies, 28 (November), 665-77.

Hoskisson, Robert E. and Michael A. Hitt (1988), "Strategic Control Systems and Relative R\&D Investment in Large Multiproduct Firms," Strategic Management Journal, 9 (November/December), 605-21.

- and - (1990), "Antecedents and Performance Outcomes of Diversification: A Review and Critique of Theoretical Perspectives," Journal of Management, 16 (June), 461-509.

and (1994), Downscoping: How to Tame the Diversified Firm. New York: Oxford University Press.

, Richard A. Johnson, and Douglas D. Moesel (1994), "Corporate Divestiture Intensity in Restructuring Firms: Effects of Governance, Strategy and Performance," Academy of Management Journal, 37 (October), 1207-51.

$\ldots$ and Thomas A. Turk (1990), "Corporate Restructuring: Governance and Control Limits of the Internal Capital Market," Academy of Management Review, 15 (July), 459-77.

Hunt, Shelby D. and Robert M. Morgan (1995), "The Comparative Advantage Theory of Competition," Journal of Marketing, 59 (April), 1-15.

Jayachandran, Satish, Javier Gimeno, and P. Rajan Varadarajan (1999), "The Theory of Multimarket Competition: A Synthesis and Implications for Marketing Strategy," Journal of Marketing, 63 (July), 49-66.

Jensen, Michael C. and William Meckling (1976), "Theory of the Firm: Managerial Behavior, Agency Costs, and Capital Structure," Journal of Financial Economics, 3 (October), 305-60.

Kohli, Ajay K. and Bernard J. Jaworski (1990), "Market Orientation: The Construct, Research, Propositions and Managerial Implications," Journal of Marketing, 54 (April), 1-18.

Leontiades, M. and A. Tezel (1981), "Some Connections Between Corporate-Level Planning and Diversity," Strategic Management Journal, 2 (October-December), 413-18.
Lewis, Tom and Arthur Peck (1991), Converging on Capabilities and Value. Boston: The Boston Consulting Group.

Lichtenberg, Frank R. (1990), "Want More Productivity? Kill the Conglomerate," Wall Street Journal, (January 16), A14.

Markides, Constantinos C. (1995), Diversification, Refocusing, and Economic Performance. Cambridge, MA: MIT Press.

Montgomery, Cynthia A. (1985), "Product-Market Diversification and Market Power," Academy of Management Journal, 28 (December), 789-98.

Montgomery, David B. and Glenn Urban (1969), Management Science in Marketing. Englewood Cliffs, NJ: Prentice Hall.

Narver, John C. and Stanley F. Slater (1990), "The Effect of a Market Orientation on Business Profitability," Journal of Marketing, 54 (October), 20-35.

Porac, Joseph F. and Jose Antonio Rosa (1996), "Rivalry, Industry Models, and the Cognitive Embeddedness of the Comparable Firm," Advances in Strategic Management, 13, 363-88.

Prahalad, C.K. and Richard A. Bettis (1986), "The Dominant Logic: A New Linkage Between Diversity and Performance," Strategic Management Journal, 7 (November/December), 485-501.

— and Gary Hamel (1990), "The Core Competence of the Corporation," Harvard Business Review, 68 (May/June), 79-91.

Scherer, Frederic M. and D. Ross (1990), Industrial Market Structure and Economic Performance. Boston: Houghton Mifflin.

Schleifer, Andrei and Robert W. Vishny (1991), "Takeovers in the 60s and the 80s: Evidence and Implications," Strategic Management Journal, 12 (Winter), 51-59.

Shepherd, W.G. (1970), Market Power and Economic Welfare. New York: Random House.

Shimp, Terence A. (1999), Advertising \& Promotion: Supplemental Aspects of Integrated Marketing Communications. Fort Worth, TX: The Dryden Press.

Srivastava, Rajendra K., Tasadduq A. Sherwani, and Liam Fahey (1998), "Market-Based Assets and Shareholder Value: A Framework for Analysis," Journal of Marketing, 62 (January), 2-18.

Varadarajan, P. Rajan and Terry Clark (1994), "Delineating the Scope of Corporate, Business and Marketing Strategy," Journal of Business Research, 31 (October/November), 93-105.

Walker, Orville C. and Robert W. Ruekert (1987), "Marketing's Interaction with Other Functional Units: A Conceptual Framework and Empirical Evidence," Journal of Marketing, 51 (January), 1-19.

Walsh, J.P. and J.I. Seward (1990), "On the Efficiency of Internal External Corporate Control Mechanisms," Academy of Management Review, 15 (July), 421-58. 